\title{
NILAI SEBUAH NAMA BAGI PEREMPUAN: Upaya Berteologi dalam Konteks Ketidakadilan Gender
}

\author{
Firman Panjaitan, Dwi Ratna Kusumaningdyah \\ Sekolah Tinggi Teologi Tawangmangu \\ panjaitan.firman@gmail.com
}

\begin{abstract}
Gender injustice is not only visible in the phenomenon of the sexual division of labor but also in the mention of a woman who is married. Generally, the personal name of a married woman will be lost, replaced by the name of her husband. This shows that in the family there is also a pattern of ordination-subordination relationships between men and women. This issue will be the focus of the discussion in this article, with the aim that gender equality can be created starting from the smallest unit in society, namely the family. By using the phenomenological method, which departs from existing facts and then analyzes it with literature studies, this article shows that a person's name refers to a person. If the name is removed and replaced with another name, that person is also lost and replaced based on the new name. This must be minimized, if necessary eliminated, by mentioning the name of a wife based on her own name without having to replace her with the name of the husband. The results of the study show that gender education has been carried out by each family through small things, especially in instilling the value of a personal name for a woman so that this will be a force to develop gender justice in society.
\end{abstract}

Keywords: gender injustice, name, women, family

\begin{abstract}
Abstrak. Ketidakadilan gender tidak hanya tampak dalam fenomena pembagian kerja secara seksual melainkan tampak juga dalam penyebutan nama seorang perempuan yang sudah bersuami. Umumnya nama pribadi perempuan yang bersuami akan hilang digantikan dengan nama suami. Hal ini menunjukkan dalam keluarga pun terjadi pola hubungan ordinasi-subordinasi antara laki-laki dan perempuan. Masalah ini yang akan menjadi sorotan pembahasan dalam artikel ini, dengan tujuan agar kesetaraan gender dapat diciptakan yang dimulai dari unit terkecil dalam masyarakat, yaitu keluarga. Dengan menggunakan metode fenomenologi, yang berangkat dari kenyataan yang ada dan kemudian dianalisis dengan studi literatur, artikel ini memerlihatkan bahwa nama seseorang menunjuk pada pribadi. Jika nama dihilangkan dan diganti dengan nama lain, maka pribadi itu pun ikut hilang dan tergantikan berdasarkan nama yang baru. Hal ini harus diminimalisasi, jika perlu dihilangkan, dengan cara menyebut nama seorang istri berdasarkan namanya sendiri tanpa harus menggantikannya dengan nama suami. Hasil kajian menunjukkan bahwa pendidikan gender yang sudah dilakukan oleh setiap keluarga melalui hal yang kecil, terkhusus dalam menanamkan nilai nama pribadi bagi seorang perempuan sehingga ini akan menjadi kekuatan untuk menumbuhkembangkan keadilan gender dalam masyarakat.
\end{abstract}

Kata-kata Kunci: ketidakadilan gender, nama, perempuan, keluarga

Dalam sebuah studi kasus, seorang perempuan pernah mengungkapkan pergumulannya sebagai berikut (Zakiyah, 1997), "Saya terlahir dengan nama yang diberikan orang tua saya, yaitu Dwi Arum 
(bukan nama sebenarnya). Nama itu diberikan kepada saya dengan dua alasan, pertama karena saya adalah anak ke dua yang lahir dari rahim ibu, dan kedua karena orang tua saya memiliki harapan, kelak, saya akan menjadi seorang perempuan yang membawa keindahan dan keharuman (meskipun kenyataannya tidak selalu demikian) bagi kehidupan. Bagi orang tua saya, nama merupakan tanda (Jawa: tenger) dan identitas diri yang melekat dalam diri serta yang membedakan saya dengan yang lain (meskipun ada banyak nama Dwi atau Arum yang lain), sekaligus mengungkapkan harapan orang tua terhadap saya sebagai anaknya."

Hal senada pernah diungkapkan oleh Karlina Leksono-Supeli (2001, 159), yang diberi nama Karlina oleh kakak perempuan tertuanya dengan alasan karena nama itu 'terdengar perempuan', dan ditambah oleh orang tuanya dengan Rohima (artinya penuh belas kasih, salah satu nama Tuhan dan bernada Islami) dan Supeli (nama ayah). Masih banyak lagi nama perempuan yang lain, baik yang diberi tambahan nama ayah/marga ataupun tidak, yang pasti nama itu adalah tanda "keberadaan dan kehadiran' seseorang di dunia ini yang membedakannya dengan yang lain, dan di dalam nama itu tersimpan setiap harapan, kenangan orang tua terhadap anaknya. Karlina $(2001,160)$ mengungkapkan bahwa nama pribadi adalah simbol pertama penggunaan bahasa untuk seorang anak yang baru lahir; kelak ia akan memergunakan nama itu untuk mengenal, menemukan, bahkan ikut menamakan dunia serta menemukan kembali dirinya di dalam dunia. Dengan nama, seseorang memunyai kemungkinan 
untuk berhubungan dengan dirinya sendiri dan yang lain secara bermakna serta untuk bertindak dengan sadar.

Namun, nama perempuan mengalami perubahan setelah ia menikah, seperti yang dialami oleh Dwi Arum di atas. Dalam narasi pergumulannya, Dwi Arum melanjutkan, "Saya menikah dengan seorang laki-laki bernama Hendra, kemudian kami berdomisili di sebuah desa kecil di Jawa Tengah sedangkan saya bekerja di Semarang. Di desa tersebut, nama saya mengalami perubahan, karena tetangga dan penduduk di sekitar kami memanggil saya dengan nama 'Bu Hendra', sesuai dengan nama suami saya; dan saya yakin bahwa pengalaman saya ini juga dialami oleh perempuan-perempuan yang lain, meskipun mungkin tidak semua. Sebenarnya saya bingung dengan nama baru tersebut, dan saya seringkali menjelaskan kepada tetangga maupun penduduk di sekitar bahwa nama saya adalah Dwi Arum, bukan 'Bu Hendra', namun penjelasan saya dipandang sebagai sesuatu yang 'aneh'. Bagi sebagian penduduk yang, nota bene, memiliki pendidikan dengan taraf menengah ke atas, penjelasan tersebut tidak menjadi persoalan, karena mereka melihat bahwa saya pun seorang perempuan yang bekerja, namun bagaimana dengan perempuan yang lain setelah mereka menikah dan tidak bekerja di luar rumah?" (Muflihah, 2013).

Pergumulan yang diungkapkan oleh Dwi Arum adalah fenomena umum di dalam masyarakat Indonesia. Memang ada sebagian kecil perempuan menikah yang memiliki profesi dan bekerja/berkarier dipanggil 
dengan namanya sendiri di lingkup pekerjaan dan relasinya, namun di tengah masyarakat mereka tetap dipanggil berdasarkan nama suami mereka. Hal ini 'dipandang lazim', bahwa perempuan yang menikah akan kehilangan namanya sendiri karena digantikan dengan nama suami mereka. Namun di balik fenomena ini muncul pertanyaan, bukankah nama itu menunjuk pada identitas seseorang sebagai subyek yang seharusnya tidak lenyap ketika terjadi pernikahan? Bukankah nama yang terpenggal sebagian, akibat penambahan nama suami, berarti menunjuk pada pribadi yang tak lagi utuh? Apakah hal ini menjadi sebuah aturan tidak tertulis yang harus ditaati oleh setiap perempuan yang menikah? Jika hal ini memang lazim, tidaklah mengherankan apabila dalam sebuah keluarga dengan istri sebagai pekerja, ia hanya dipandang sebagai pribadi yang membantu perekonomian keluarga dan tidak akan bisa dihargai sebagai pencari nafkah keluarga (Bertrand et al., 2015).

Meskipun tampak sepele, tetapi sesungguhnya fenomena ini menampakkan adanya ketidakadilan gender karena dengan tidak menyebut nama pribadi perempuan setelah menikah, maka hal ini seolaholah menafikan keberadaan seorang perempuan dalam lingkup domestik. Panjaitan mengategorikan kasus ini sebagai bentuk kekerasan dalam rumah tangga (Panjaitan, 2018). Penyebutan nama pribadi adalah bentuk dari sebuah penghargaan terhadap kehadiran dan keberadaan seseorang, oleh sebab itu nama tidak laik untuk dihilangkan dan diganti dengan nama lain, yang bukan nama aslinya. Nama menghadirkan dan sekaligus adalah 
identitas diri, karena itu jangan pernah dihilangkan atau diganti dengan alasan apa pun. Berdasar hal ini, maka tulisan dalam artikel ini bertujuan hendak menyoroti tentang bentuk ketidakadilan gender yang bermuara pada ketiadaan pengakuan terhadap nama seorang perempuan, khususnya ketika ia berumah tangga; dan menawarkan sebuah tindakan solutif untuk mengembangkan bentuk keadilan gender dalam lingkup domestik, secara khusus, dan dalam lingkup kemasyarakatan, secara umum.

\section{METODE}

Pembahasan dalam artikel ini menggunakan pendekatan fenomenologis, di mana langkah pertama yang penulis lakukan adalah terlebih dahulu mendeskripsikan suatu obyek, fenomena atau setting sosial yang dituangkan dalam tulisan yang bersifat naratif (Anggito \& Setiawan, 2018). Langkah berikutnya, dengan menggunakan metode studi literatur, penulis berusaha mengumpulkan data dari sumber-sumber literatur yang berkorelasi dengan masalah dan pokok bahasan untuk dianalisis. Analisa data dilakukan dengan cara memaparkan obyek yang diteliti dalam bentuk uraian narasi untuk diinterpretasi, baik secara budaya, sosial maupun hermeneutik Alkitabiah. Setelah analisis dilakukan terhadap data yang diperoleh dari berbagai sumber literatur, maka disusunlah sebuah kesimpulan dan sekaligus rekomendasi bagi terbentuknya upaya berteologi dalam konteks ketidakadilan gender. 


\section{HASIL}

Banyak orang menganggap bahwa ketidakadilan dan kekerasan gender hanya terjadi melalui tindakan fisik, namun sesungguhnya itu hanya sebagian dari fenomena yang ada. Kekerasan dan ketidakadilan gender, justru, seringkali terjadi melalui rindakan-tindakan non-fisik, misalnya melalui verbal atau penghadiran jargon-jargon atau sesantisesanti yang kelihatannya netral tetapi sebenarnya bernilai berat sebelah. Hal ini tampak saat penyebutan nama perempuan yang digantikan dengan nama suami, ketika perempuan itu menikah. Kelihatannya kasus seperti ini sepele dan biasa-biasa saja, tetapi sebenarnya ini merupakan tindakan tersistematisasi dan terstruktur untuk mendegradasi keberadaan seorang perempuan dengan cara meniadakan nama. Nama adalah pemberian orang tua yang mencirikan identitas dan keberadaan seseorang, ketika nama itu diganti dan dihilangkan maka sesungguhnya keberadaan dan identitas si pemilik nama tergantikan dan tertiadakan/ternafikan.

Di samping itu, dengan mengubah nama perempuan dan menyandangkan nama suami sebagai nama perempuan tersebut sebenarnya menunjukkan adanya kepemilikan suami terhadap perempuan. Seperti halnya yang dihadirkan melalui pemahaman istilah family, yang menunjukkan tentang kepemilikan, maka dalam sistem keluarga tersebut terjadi kepemikan seorang laki-laki, sebagai suami, terhadap perempuan, sebagai istri. 
Melalui reinterpretasi terhadap pemahaman-pemahaman Alkitab yang semula dipahami dan ditafsir secara berat sebelah untuk menunjukkan kondisi ordinasi-subordinasi antara laki-laki dan perempuan, dapat ditemukan bahwa Alkitab senantiasa memerlihatkan kondisi yang setara dan sejajar dalam kedudukan laki-laki dan perempuan. Laki-laki bergantung pada perempuan, demikian juga sebaliknya dan dalam saling kebergantungan tersebut, mereka sangat menggantungkan harapan hanya kepada Tuhan saja. Jika laki-laki dan perempuan ada dalam posisi yang setara dan sejajar, maka salah satu tindakan untuk menunjukkan kesetaraan itu adalah dengan cara memanggil nama-nama perempuan sesuai dengan nama mereka, tanpa harus menafikan nama yang berarti menafikan kehadiran.

\section{PEMBAHASAN}

Bagi masyarakat Indonesia, masalah nama bukan sekadar pencantuman belaka melainkan memiliki makna yang lebih dalam dan berarti. Nama adalah identitas sekaligus jatidiri seseorang. Nama menunjukkan keberadaan seseorang dan bahkan nama dapat dikatakan sebagai gambaran utuh tentang harapan terhadap masa depan si pemilik nama tersebut (Leksono-Supeli, 2001). Bahkan secara teologis dapat dikatakan bahwa nama merupakan wujud dari keberadaan si pemilik nama itu secara utuh sekaligus menunjukkan sifat-sifatnya. Graham menunjukkan bahwa jika Allah itu dinamakan dengan TUHAN, maka hal ini menunjukkan tentang keberadaan Allah tetapi sekaligus sifat-sifat yang 
melingkupi nama dan pribadi tersebut (Graham, 2011). Tetapi jika nama itu dihilangkan dari sosok Allah, maka keberadaan Allah menjadi nihil, kosong dan tidak berarti. Oleh sebab itulah, tambah Graham, Alkitab menjelaskan bahwa setiap nama yang diberikan memiliki konsekuensi logis terhadap cara dan gambaran kehidupan masa kini dan yang akan datang dari si pemilik nama tersebut.

Terkait dengan hal di atas, Swinton (2014) mengungkapkan bahwa di dalam nama terkandung sebuah kekuatan yang mendorong seseorang untuk hidup dan berjalan menurut nama yang diembannya. Kekuatan ini sekaligus menjadi alasan utama bagi seseorang untuk memertahankan kehidupan yang dimiliki dan dijalaninya. Penjelasan ini semakin menandaskan bahwa nama bukanlah sekadar sebuah tulisan atau atribut yang dikenakan kepada seseorang atau sesuatu, namun merupakan simbolisasi langsung dari keberadaan masa kini dan yang akan datang dari si pemilik nama tersebut. Hal inilah yang menjadi landasan dasar dari setiap suku yang ada di Indonesia untuk memberikan nama terhadap anak-anak mereka (Leksono-Supeli, 2001). Jadi dapat dipahami sekarang, jika nama dinafikan maka hal itu berimbas langsung terhadap kehidupan dan eksistensi si pemilik nama yaitu mengalami pengasingan/alienasi.

Meski nama itu mewakili keberadaan seseorang, namun secara umum di kalangan masyarakat yang menganut sistem kehidupan patriarkhi, penggantian nama seorang perempuan yang telah kawin dengan nama suami sudah menjadi sebuah kebiasaan yang dinilai wajar 
dan tidak memiliki konsekuensi apa pun, karena perubahan nama itu terjadi akibat perubahan status dari lajang menjadi bersuami. Bersuami berarti menjadi milik suami.

Hal tersebut senada dengan teori nurture yang dimunculkan oleh Friederich Engels, seperti yang dikutip oleh Panjaitan (2018), yang mengatakan bahwa ketika seorang perempuan memasuki masa perkawinan, maka ia harus merelakan dirinya untuk dimiliki oleh laki-laki yang diakuinya sebagai suami. Karena sebuah perkawinan akan membentuk sebuah keluarga, dan kata 'keluarga' itu sendiri berasal dari kata famulus (asal kata family), yang secara harfiah berarti 'kepemilikan'. Siagian memerlihatkan hal ini dengan jelas dalam sebuah contoh, yaitu budaya Batak, yang menegaskan bahwa seorang perempuan adalah bagian dari kerabat ayahnya saat gadis dan setelah menikah akan menjadi bagian dari kelompok kekerabatan suaminya, yang ditandai dengan memakai nama dan marga suami (Siagian, 2019). Jadi, ketika masih lajang seorang anak perempuan milik orang tuanya/keluarga ayahnya, ketika menikah ia menjadi milik suami. Dari kenyataan ini tampak bahwa pernikahan menjadikan perempuan memiliki status yang lebih (di)rendah(kan) dari laki-laki dan tersubordinasikan (Siagian, 2019).

Keberadaan seorang perempuan sebagai istri untuk mendukung keberadaan suaminya, taat/berbakti kepada suami, sebagaimana yang dikutip oleh Sukri dan Sofwan dari tulisan Serat Candrarini sebagai berikut (Sukri \& Sofwan, 2001, hal. 72): 
Sungku sungkeme ngawula maring kakung, pangrengkuhe Bathara Di, ngudi kawidadanipun, jrih terus ing lahir batin, cundhuk cumadhong ing karso (megatruh, bait 42,43)

artinya:

Adapun bakti dan mengabdinya (seorang istri) kepada suami seperti baktinya pada Dewa, mencari kebahagiaan lahir maupun batin, tunduk patuh serta siap melaksanakan apa yang dikehendaki.

Dalam hal ini Asmarani (2017) menambahkan bahwa ketaatan seorang istri kepada suami sampai pada kesediaan dan kerelaan yang tanpa terpaksa untuk dimadu dan hidup rukun bersama madunya bagi istri para bangsawan/priyayi

Selain perempuan dituntut untuk hidup dalam status sebagai istri yang baik, ia juga dituntut memiliki status sebagai seorang ibu bagi anakanak yang dilahirkan dari rahim yang dibuahi oleh suaminya. Pemahaman kata 'Ibu' di sini menjelaskan bahwa perempuan adalah sumber utama dari tindakan pengasuhan, kenyamanan, kebaikan, ketergantungan, ajaran dan kepemimpinan; dia penuh perhatian, memahami perasaan anak dan tahu apa yang baik bagi mereka (Mulder, 1999, hal. 137-138). Namun sayangnya, seperti yang disitir oleh Soetrisno (1999, pp. 69-76), konsep tentang 'ibu' ini telah mengalami politisasi ketika Orde Baru berkuasa melalui ideologi pembangunan yang seolah-olah mengangkat harkat perempuan, namun sebenarnya semakin membuat perempuan terpuruk menjadi korban pembangunan. Fakih (1997, pp. 25-29) menambahkan bahwa politisasi pemahaman kata 'ibu' di sini sebenarnya hendak memerlihatan sebuah pemuliaan semu yang dibangun dalam sebuah konstruksi terhadap subyek seorang perempuan yang 
diciriutamakan dengan kepatuhan. Perempuan ibarat menerima amanat sakral ketika bertemu dengan konsep diri sebagai seorang 'ibu' yang merupakan pembina keluarga dalam rangka mewujudkan keluarga dan masyarakat yang memunyai ketangguhan mental, budaya dan agama. Kesemuanya ini kemudian digabungkan dalam sebuah konsep besar tentang perempuan yang ditempatkan sebagai 'sumber daya manusia dalam pembangunan' (Asmarani, 2017).

Alih-alih konsep besar tersebut tampak seperti upaya untuk memuliakan perempuan, namun sebenarnya itu hanyalah 'jargon kosong' yang sengaja dimunculkan untuk melemahkan kedudukan seorang perempuan, karena dalam kenyataannya keberadaan perempuan semakin dimarginalkan dari area publik, lalu dibungkam dalam dunia politik, bahkan dituntut untuk beban yang sangat berat di area domestic (Anggradinata, 2016). Dengan penerapan jargon kosong tersebut, maka rusaknya moralitas dan hidup keluarga dan generasi mendatang ditumpangkan tanggungjawab sepenuhnya kepada seorang ibu, sementara itu kebobrokan moral laki-laki, dalam hal ini diwakili oleh sosok ayah, tidak terlalu dipersoalkan seperti ibu. Situasi inilah yang memunculkan fenomena bahwa posisi seorang perempuan sebagai ibu menjadi tumpuan kesalahan di dalam keluarga maupun masyarakat (Souisa, 2016).

Dari penelusuran yang tersaji di atas, tampak adanya bentuk ketidakadilan yang dialami perempuan ketika memasuki sebuah 
perkawinan, yaitu: pertama, dalam perkawinan seorang perempuan akan memiliki status baru yang ditandai dengan kehilangan nama dan diganti dengan nama suaminya. Kedua, dalam status barunya yang diwakilkan melalui nama suami, maka perempuan mengalami kondisi tersubordinasikan dari suaminya. Ketiga, melalui perkawinan seorang perempuan akan memasuki masa untuk menanggung beban yang berat dengan fungsinya sebagai 'ibu', karena dengan menyandang gelar 'ibu' ia sedang memersiapkan generasi mendatang yang harus baik dan cemerlang (Nasri, 2017).

Semua kondisi ini terjadi karena kuatnya budaya patriakhi yang bermuatan dominasi laki-laki terhadap perempuan, dan di mana ada dominasi pasti di situ pula terjadi ketidak adilan. Tidak dapat dipungkiri bahwa agama pun seringkali menjadi dasar legitimasi teologis untuk menomorduakan perempuan dalam praktik kehidupan bermasyarakat. Ihromi (1986, pp. viii-ix) menyebutkan contoh-contoh yang jelas dalam praktik keagamaan mengenai kedudukan yang rendah dari seorang perempuan. Dalam tradisi agama Hindu diajarkan bahwa seorang perempuan ideal (disebut sati) adalah seorang perempuan menikah yang harus merelakan dirinya untuk ikut mati membakar diri dalam pembakaran mayat suami sebagai wujud kesetiaan kepada suami. Dalam tradisi agama Budha dikenal tentang status perempuan sebelum menikah yang memiliki ketergantungan mutlak kepada ayah, lalu pada saat menikah ia bergantung kepada suami dan di hari tuanya bergantung kepada anak 
laki-lakinya. Di kalangan pemeluk Islam, dijinkannya perkawinan poligami, meskipun dengan azas keadilan, tetapi sesungguhnya perkawinan dengan azas ini telah menempatkan perempuan lebih rendah dari pada laki-laki. Akhirnya, dalam kekristenan sendiri digambarkan bahwa penciptaan perempuan merupakan penciptaan yang terkemudian dan ia terjadi dari tulang rusuk Adam (Kej. 2:15-22), bahkan dalam I Korintus 11:7 tergambarkan bahwa kedudukan seorang perempuan berada di bawah laki-laki karena keberadaan seorang perempuan adalah untuk menyinarkan kemuliaan laki-laki (Panjaitan, 2020).

Harus diakui bahwa wahyu Allah kepada manusia diterima oleh manusia yang berbudaya patriakhi, sehingga nuansa yang muncul dalam agama itupun bersifat maskulin. Demikian juga halnya dengan ajaran kekristenan, warisan ini pun lahir dan dilestarikan dalam budaya Patriakhi. Namun demikian patut dicermati dengan lebih jujur, bahwa tidak semua bagian dari Alkitab selalu menempatkan perempuan lebih rendah dari lakilaki, meskipun konsep-konsep tradisional yang diwarisi dari para penafsir terdahulu maupun tafsiran masa kini banyak yang menguatkan dan melegitimasi dominasi laki-laki terhadap perempuan.

Bila kesaksian penulis kitab Kejadian dicermati dengan seksama, khususnya yang menceritakan tentang para ibu-ibu leluhur, misalnya dalam Kejadian 16:1 disebutkan nama Sarai, istri Abram (diulang dalam ayat-ayat berikutnya, bahkan bagian-bagian yang lain seputar cerita Abram) juga Hagar (ayat 3), Kejadian 25:20,21 diungkapkan tentang 
nama Ribka, istri Ishak, lalu Kejadian 29:1-30 yang berisi kisah tentang Lea, Rahel, dan istri-istri Yakub. Dari contoh-contoh ini dapat dilihat bahwa penulis kitab Kejadian dengan sengaja mencantumkan dan menyebut nama-nama perempuan yang menjadi ibu leluhur bangsa Israel. Meskipun berstatus sebagai istri, di mana dalam budaya patriakhi mereka harus tunduk, setia, bahkan dengan sukacita dimadu demi keturunan yang wajib mereka berikan kepada suami, namun mereka sama sekali tidak kehilangan nama yang diberikan orang tua mereka. Alkitab menunjukkan bahwa nama mereka adalah pribadi mereka itu sendiri, yang diungkapkan dalam kehadiran mereka yang aktif di dunia ini. Status mereka sebagai istri tidak meniadakan/menafikan ataupun mengurangi nama mereka, dan pribadi mereka tetap utuh yang disimbolkan melalui nama-nama mereka. Apa yang dilakukan penulis kitab Kejadian ini patut direnungkan kembali dengan jujur bahwa di tengah kuatnya budaya patriakhi, masih ada upaya untuk menempatkan perempuan yang telah menikah sebagai pribadi yang ada, utuh di samping suaminya (Harisantoso, 2020).

Kejadian 3:20 seringkali dipakai sebagai dasar teologis bagi lakilaki untuk menguasai perempuan, karena dialah yang memberi nama Hawa kepada perempuan itu (istrinya). Memberi nama seringkali dikaitkan dengan menguasai, karena yang memunyai hak memberi nama pastilah memunyai kedudukan di atas yang diberi nama, misalnya orang tua memberi nama pada anaknya. Bahkan dalam Kejadian 2:19-20 digambarkan bahwa manusia laki-laki itu memberi nama pada tiap-tiap 
makhluk hidup yang telah dibentuk oleh Tuhan, dan itu menunjukkan dominasi laki-laki terhadap binatang. Namun bisakah Kejadian 3:20 ditafsirkan demikian?

Singgih (1999) berpendapat bahwa Kejadian 3:20 tidak dapat ditafsirkan sebagai bentuk penguasaan, karena berbeda sifatnya dengan pemberian nama kepada binatang-binatang, dan hal ini tampak dalam urutan penempatan yang tidak bersamaan, ada jarak 23 ayat dari antara pemberian nama kepada binatang dan perempuan. Kejadian 2:19-20 menunjukkan bagaimana Tuhan membuat binatang dalam rangka mencari penolong yang sepadan bagi manusia laki-laki yang telah diciptakan-Nya, namun usaha tersebut tidak membuahkan hasil yang diharapkan. Sesudah perempuan diciptakan, manusia tidak memberi nama pada perempuan, seperti yang dilakukan pada ayat-ayat sebelumnya (terhadap binatang). Hal penamaan itu justru terjadi sesudah mereka menerima hukuman Tuhan, dan ini berarti bahwa 'penolong yang sepadan' itu baru dialami secara nyata dalam pergumulan bersama. Pendapat ini tentu saja dapat diterima, karena memang ada konteks yang sudah berbeda antara Kejadian 2:19-20 dan Kejadian 3:1-24. Dengan demikian Kejadian 3:20 tidak dapat dipakai sebagai landasan untuk melegitimasi penguasaan suami terhadap istri (laki-laki terhadap perempuan).

Bagian dari Perjanjian Lama yang lain, yang patut diperiksa ulang adalah Kejadian 2:21-23, yaitu cerita tentang perempuan yang diciptakan dari tulang rusuk Adam (laki-laki). Singgih (1999) menafsirkan bagian ini 
sebagai berikut, istilah 'tulang rusuk' diterjemahkan dari kata tselot, yang memiliki arti harfiah 'sisi, bagian samping, atau separuh'. Jika demikian, seorang perempuan terjadi karena diambil dari laki-laki, dan ia adalah separuh dari laki-laki. Itulah sebabnya kata yang diterjemahkan dengan perempuan dalam Kejadian 2 adalah isysyah yang berasal dari isy; dan jika diamati sebenarnya kata isysyah adalah bentuk feminin dari isy. Jadi, jika isy diterjemahkan dengan kata laki-laki (lelaki), maka isysyah sebaiknya diterjemahkan dengan lelaki-wati.

Untuk melukiskan penciptaan perempuan dipakai kata 'membangun' (banah), yang tergolong dalam perbendaharaan bahasa arsitektur dan sering digunakan untuk menggambarkan pembuatan sesuatu yang sophisticated. Dalam ayat 23, Singgih (1999), yang mengikuti pola pikir Phyllis Trible seorang penafsir perempuan, mengungkapkan bahwa ayat ini tidak bersangkut paut dengan pemberian nama pada binatang, karena kata kerja qara, yang diterjemahkan dengan kata 'menamakan atau menyebutkan', adalah kata kerja yang berdiri sendiri tanpa memiliki obyek. Jadi di sini kata qara lebih tepat jika diterjemahkan dengan kata 'menyebutkan atau mengenali', bukan 'menamakan' seperti yang dilakukan oleh LAI. Dari penjelasan tersebut, Singgih menyimpulkan bahwa konteks perikop ini hendak menunjukkan bahwa perempuan dan laki-laki diciptakan setara, tidak ada yang lebih atau yang kurang dari pada yang lain. Dalam hal ini penulis setuju terhadap tafsiran Singgih, karena Kejadian 2:21-23 merupakan satu 
bagian dengan Kejadian 2:18-20 yang menyaksikan tentang bagaimana Tuhan mengupayakan adanya penolong yang sepadan terhadap laki-laki, yang hanya dapat dijumpai dalam diri manusia perempuan.

Melalui tafsiran ini, menjadi jelas bahwa cerita penciptaan perempuan dari tulang rusuk laki-laki tidak dapat dipakai sebagai landasan untuk melegitimasi dominasi laki-laki terhadap perempuan, bahkan sebaliknya memerlihatkan kesetaraan/kesepadanan laki-laki dan perempuan, yang tidak berubah meskipun terjadi pernikahan, bahkan makna perempuan sebagai penolong yang sepadan semakin konkret dalam pergumulan bersama laki-laki di dalam kehidupan ini.

Di bagian lain I Korintus 11:7, yang merupakan bagian dari ayat 216, seolah-olah menampakkan dukungan terhadap subordinasi perempuan dari laki-laki. Tak dapat dipungkiri bahwa Paulus berada dan hidup dalam budaya Yahudi-Helenis yang patriakhi dan jemaat di Korintuspun berada dalam situasi yang sama dengan Paulus. Menanggapi hal ini, Singgih (1999) mengatakan bahwa memang ada logika pemikiran yang menempatkan perempuan di bawah laki-laki dalam perikop ini, khususnya ayat 7 dan 8 . Namun hal itu sebenarnya bukan satu-satunya masalah, masih ada hal lain yang seolah-olah tidak dianggap sebagai masalah. Apabila diperhatikan ayat 11 sampai dengan 12, maka tampak perubahan dalam penjelasan Paulus, karena sehabis ayat 11 yang mengatakan bahwa perempuan menyinarkan kemuliaan laki-laki, ayat 12 menegaskan bahwa, "Namun demikian, dalam Tuhan tidak ada 
perempuan tanpa laki-laki dan tidak ada laki-laki tanpa perempuan. Sebab sama seperti perempuan berasal dari laki-laki, demikian pula laki-laki dilahirkan oleh perempuan; dan segala sesuatu berasal dari Allah."

Dalam perikop ini Paulus ingin memberikan pengertian secara hatihati (tidak radikal), namun sebenarnya hendak mengungkapkan hal yang cukup prinsip yaitu laki-laki dan perempuan sama-sama ciptaan Allah, sama-sama makhluk. Sedangkan untuk menjawab masalah-masalah praktis dalam jemaat, Paulus meminta jemaat untuk memertimbangkan sendiri sesuai apa yang telah diajarkan oleh Paulus selama ini. Sekali lagi dalam bagian ini, ternyata tidak dapat ditarik begitu saja dari konteks perikop untuk membenarkan gagasan menempatkan perempuan di bawah laki-laki, bahkan menurut Paulus sendiri, laki-laki dan perempuan samasama ciptaan Allah. Tentunya hal ini secara tidak langsung menyiratkan kesamaan derajat laki-laki dan perempuan (Singgih, 1999).

Demikian juga halnya dengan Efesus 5:22-33, yang merupakan bentuk aturan kerumah-tanggaan yang lazim ada dalam masyarakat Helenis yang diadopsi oleh Paulus, sesuai dengan kebutuhan jemaat. Prinsip Paulus yang berbeda dengan aturan kerumah-tanggaan Helenis, diperlihatkan melalui permainan kata tunduklah (Yun.: hupotasseste) dan kasihilah (Yun.: agapathe). Paulus hendak menguraikan makna mengasihi secara luas dan dalam. Inilah hubungan timbal balik yang khas Paulus. Bukan hanya istri saja yang tunduk, menyerahkan diri kepada suami, sebaliknya suamipun menyerahkan diri sebagai ungkapan kasihnya 
kepada istrinya. Jadi keduanya berada dalam ketundukan satu sama lain sebagaimana ketundukan Jemaat kepada Kristus yang telah menyerahkan diri bagi jemaat.

Dari perikop inipun tampak bahwa status sebagai istri bukanlah bentuk ketundukan seperti yang ada dalam konsep budaya patriakhi pada umumnya, namun ketundukan yang diiringi dengan ketundukan suami terhadap istri. Keduanya berada pada prinsip saling melayani, saling menghormati dan saling menjaga kekudusan hidup. Bagaimana terhadap anak-anak? Siapa yang bertanggung jawab atas moralitas dan kehidupan anak-anak? Mari lihat ayat-ayat selanjutnya dalam Efesus 6:1-4. Ayat 1 mengungkapkan bahwa yang harus ditaati oleh anak-anak adalah orang tua (Yun.: goneusin), berarti ayah dan ibu, ayat 2, menunjuk secara langsung, yaitu 'ayahmu dan ibumu'. Ayat 4 menunjuk pada ayah (Yun.: pateres), sebagai pribadi yang dilarang untuk menimbulkan kemarahan dalam diri anak dan diperintah untuk mendidik anak-anak tentang ajaran Tuhan. Dengan sangat jelas Paulus memerlihatkan bahwa pendidikan anak, khususnya moralitas dan spiritualitas, adalah tanggung jawab orang tua, ayah dan ibu atau suami dan istri, bukan hanya istri dalam fungsinya sebagai ibu. Bahkan ayah bukan hanya berkewajiban memenuhi kebutuhan finansial saja namun juga sebagai orang yang dekat dan patut dicontoh.

Dari seluruh pengajian ulang terhadap beberapa bagian Alkitab, dapat disimpulkan bahwa ada bagian-bagian dari Alkitab yang peduli 
terhadap perempuan, yang mengungkapkan bahwa pernikahan tidak membuatnya harus kehilangan nama dirinya. Status sebagai istri bukanlah merupakan subordinasi dengan suaminya, namun ada dalam posisi kesetaraan/kesepadanan yang diungkapkan secara nyata dalam kehidupan bersama di dalam rumah tangga (Panjaitan, 2019). Hal ini juga mengimplikasikan bahwa tanggung jawab pengasuhan dan pendidikan anak merupakan tanggung jawab bersama suami dan istri dalam rumah tangga. Dengan demikian Alkitab tidak melegitimasi adanya bentukbentuk ketidakdilan gender meskipun Alkitab, cenderung, dibungkus dalam budaya Patriakhi.

\section{KESIMPULAN}

Memanggil nama setiap perempuan yang telah menikah berarti mengakui keberadaannya sebagai pribadi yang utuh, yang ada untuk memberi makna dalam kehidupan. Memanggil nama setiap perempuan yang telah menikah dengan namanya sendiri, berarti mengakui kehadirannya sebagai subyek, sebagai penolong yang sepadan bagi sesamanya. Memanggil nama setiap perempuan yang telah menikah dengan namanya sendiri berarti mengakui bahwa fungsinya sebagai ibu dapat terlaksana dengan baik bila dilakukan dalam kebersamaan dengan suami, karena sebagai manusia ia memiliki batas-batas/kelemahan dan kehadirannya bersama suami adalah untuk saling menolong, melengkapi satu sama lain, seperti mata uang yang bersisi dua. Karena Pernikahan 
adalah rahmat Tuhan bagi manusia, maka manusia bertanggung jawab untuk menghayatinya dalam keadilan di tengah dunia yang adil pula.

\section{DAFTAR PUSTAKA}

Anggito, A., \& Setiawan, J. (2018). Metodologi Penelitian Kualitatif. Jejak.

Anggradinata, L. P. (2016). Rekonstruksi Citra Perempuan dalam Alkitab pada Kumpulan Puisi Perempuan yang Dihapus Namanya Karya Avianti Armand. Konferensi Internasional Feminisme: Persilangan Identitas, Agensi dan Politik (20 Tahun Jurnal Perempuan), 123-153.

Asmarani, R. (2017). Perempuan Dalam Perspektif Kebudayaan. Sabda: Jurnal Kajian Kebudayaan, 12(1), 7-16. https://doi.org/10.14710/sabda.v12i1.15249

Bertrand, M., Kamenica, E., \& Pan, J. (2015). Gender identity and relative income within households. Quarterly Journal of Economics. https://doi.org/10.1093/qje/qjv001

Fakih, M. (1997). Analisis Gender dan Transformasi Sosial. Pustaka Pelajar Offset.

Graham, L. (2011). The Power of Names. Theology and Science, 9(1), 157-174.

https://doi.org/https://doi.org/10.1080/14746700.2011.547020

Harisantoso, I. T. (2020). Proses Perceraian Dalam Perspektif Martin Buber. Visio Dei: Jurnal Teologi Kristen, 2(2), 329-350. https://doi.org/10.35909/visiodei.v2i2.168

Ihromi, T. O. (1986). Pendahuluan. In J.C. Vergouwen (Ed.), Masyarakat dan Hukum Adat Batak Toba (1 ed.). Pustaka Azet.

Leksono-Supeli, K. (2001). Kapan Perempuan Boleh Menamakan Dunia? In B. Kieser (Ed.), Tulus Seperti Merpati, Cerdik Seperti Ular. Kanisius.

Muflihah. (2013). Aktualisasi Diri Perempuan di Tengah Kepentingan Domestik dan Publik. Palastren, 6(1), 201-222.

Mulder, N. (1999). Agama, Hidup sehari-hari dan Perubahan Budaya, Jawa, Muangthai dan Filipina. PT Gramedia Pustaka Utama.

Nasri, D. (2017). Ketidakadilan Gender Terhadap Perempuan Dalam Novel Padusi Karya Ka'Bati. Madah: Jurnal Bahasa dan Sastra, 7(2), 225. https://doi.org/10.31503/madah.v7i2.431

Panjaitan, F. (2018). Kekerasan Terhadap Istri dalam Lingkup Domestik (Suatu Tinjauan Etis Kristiani Tentang Kekerasan Terhadap Keluarga). 
Fidei: Jurnal Teologi Sistematika dan Praktika, 1(1), 42-67. https://doi.org/10.34081/fidei.v1i1.3

Panjaitan, F. (2019). Memaknai Penyelamatan Zipora terhadap Rencana Pembunuhan Musa oleh Tuhan. Bia': Jurnal Teologi dan Pendidikan Kristen Kontekstual, 2(2), 264-277. https://doi.org/10.34307/b.v2i2.71

Panjaitan, F. (2020). Ekualitas antara Laki-laki dan Perempuan: Upaya Mereduksi Kekerasan secara Domestik. Thronos: Jurnal Teologi Kristen, 1(2), 58-72.

Siagian, R. J. (2019). Sahala Kepemimpinan Perempuan Dalam Konteks Masyarakat Batak dan Alkitab. Visio Dei: Jurnal Teologi Kristen, 1(1), 122-140. https://doi.org/10.35909/visiodei.v1i1.13

Singgih, E. G. (1999). Dunia yang Bermakna: Kumpulan Karangan Tafsir Perjanjian Lama. Persetia.

Soetrisno, L. (1999). Kemiskinan, Perempuan, dan Pemberdayaan. Kanisius.

Souisa, N. N. (2016). "Ombak Panggil Ombak" Pandangan Feminis Protestan Indonesia mengenai Pergulatan Agama, Tradisi dan Perubahan Sosial Masyarakat. Konferensi Internasional Feminisme: Persilangan Identitas, Agensi dan Politik (20 Tahun Jurnal Perempuan), 171-197.

Sukri, S. S., \& Sofwan, R. (2001). Perempuan dan Seksualitas dalam Tradisi Jawa. Gama Media.

Swinton, J. (2014). What's in A Name? International Journal of Practical Theology, 18(2), 234-247. https://doi.org/https://doi.org/10.1515/ijpt2014-0017

Zakiyah, W. (1997). Kekerasan Terhadap Istri: Suatu Tinjauan Viktimologi. In Rifka Annisa (Ed.), Menggugat Harmoni. Rifka Annisa Women's Crisis Center. 